\title{
TNF $\alpha$ and IL10 SNPs act together to predict disease behaviour in Crohn's disease
}

\author{
E V Fowler, R Eri, G Hume, S Johnstone, N Pandeya, D Lincoln, D Templeton, G L Radford-Smith
}

J Med Genet 2005;42:523-528. doi: 10.1136/jimg.2004.027425

Background: The cytokines tumour necrosis factor (TNF) $\alpha$ and interleukin (IL) 10 have been implicated in the pathogenesis of Crohn's disease (CD), with increased concentrations reported in patients with active disease. However, limited data exist on their effects on disease phenotype in the same population. Certain single nucleotide polymorphisms (SNPs) within the promoter region of the IL10 (-1082G/A, -592C) A) and $T N F \alpha(-308 G / A,-857 C / T)$ genes have been associated with altered levels of circulating IL10 and TNF $\alpha$. Methods: We conducted an Australian based case-control study (304 CD patients; 231 healthy controls) of these four SNPs. Further investigation of two SNPs was conducted using a logistic regression analysis.

Results: We identified a possible association of both IL10 SNPs and TNF $\alpha-857$ with CD. Further investigation of a relationship with disease severity showed a significant association of higher producing IL10-1082G and TNF $\alpha$ $857 \mathrm{C}$ alleles with stricturing behaviour, which was strongest when these alleles were combined and persisted after multivariate analysis ( $p=0.007$; odds ratio (OR) $2.37,95 \%$ $\mathrm{Cl} 1.26$ to 4.43 ). In addition, the TNF $\alpha-857 \mathrm{CC}$ genotype was independently associated with familial $C D(p=0.03 ; O R$ $3.12 ; 95 \% \mathrm{Cl} 1.15$ to 8.46 ).

Conclusion: These two SNPs may help to predict disease behaviour in CD patients, which may be clinically useful in shaping treatment of the disease at an earlier stage.

C ohn's disease (CD) is a complex, chronic inflammatory disorder that can affect any part of the gastrointestinal tract. The aetiology of the disease has not been fully elucidated but is based on the concept of a genetically susceptible host encountering a single or a series of environmental "hits" to manifest the disease phenotype. At least one major CD susceptibility gene, CARD15, has recently been identified, and directly implicates the innate immune system in the pathogenesis of this disease. ${ }^{2}$ Other potential $C D$ susceptibility genes implicating the intestinal epithelium, and located on chromosomes 5 and 10, remain to be confirmed in independent datasets. ${ }^{3}$

A number of cytokines have been invoked in the chronic inflammatory lesions of $\mathrm{CD}$ patients, in particular tumour necrosis factor (TNF) $\alpha$ and interleukin (IL) 10. Evidence for a central role for $\mathrm{TNF} \alpha$ in $\mathrm{CD}$ comes from both human work and animal models, including measurement of TNF $\alpha$ in stool and intestinal tissue, ${ }^{5}{ }^{6}$ and the development of the TNF $\triangle \mathrm{ARE}$ and SAMPI/Yit murine models of CD, which overexpress TNF $\alpha$ and develop a chronic, granulomatous ileitis similar to human CD. ${ }^{7}$ The role of IL10 in CD pathogenesis was initially suggested by development of enterocolitis in IL10 knockout mice, and because of its potentially important role as an immunoregulatory cytokine. ${ }^{8}$ Cytokine (ILl0) and anticytokine $(\mathrm{TNF} \alpha)$ strategies have also been exploited in $\mathrm{CD}$ treatment, with the latter proving successful in the form of anti-TNF $\alpha$ monoclonal antibodies. ${ }^{10}$ However, IL10 has not demonstrated significant efficacy over placebo in large, randomised studies in CD, and importantly, the inflammatory lesion seen in the IL10 knockout is predominantly colitis, with no ileal involvement seen in longitudinal studies. ${ }^{11}{ }^{12}$

In view of their central role in initiation and control of the inflammatory response, and in other pathways including apoptosis, TNF $\alpha$ and ILl0 are attractive candidate susceptibility and/or modifier genes for CD. Hence, TNF $\alpha$ and IL10 may be regulated at the transcriptional level, as several single nucleotide polymorphisms (SNPs) in the promoter regions of both genes have been associated with changes in expression levels. ${ }^{13}{ }^{14}$ Promoter region SNPs in IL10 (-1082G allele) and $\mathrm{TNF} \alpha(-308 \mathrm{~A}$ allele, $-857 \mathrm{C}$ allele) genes have been associated with significantly higher levels of circulating IL10 and TNF $\alpha$, respectively. ${ }^{13-16}$ A second IL10 promoter SNP (-592) has also been implicated in $\mathrm{CD}$; however, its functional relevance remains unclear. $^{17}$ Several studies have shown significant association between these SNPs and patients with CD,,$^{15} 1819$ but others have been unable to confirm this. ${ }^{18}{ }^{20-22}$

No study to date has analysed both TNF $\alpha$ and IL10 polymorphisms in the same population, despite the polygenic nature of $\mathrm{CD}$ and the potentially important interaction between these cytokines within the mucosa. Although these cytokines have previously been regarded as pro-inflammatory $(\mathrm{TNF} \alpha)$ and immunoregulatory (IL10), this concept may now be too simplistic. ${ }^{23}$ In fact, both TNF $\alpha$ and IL10 activate CD $8^{+}$ $\mathrm{T}$ cells, which have been strongly implicated in the pathogenesis of the $\mathrm{CD}$ phenotype displayed by the TNF $\triangle$ ARE mouse. ${ }^{723}$ Another potential immunostimulatory role for IL10 has been observed during some of its pivotal trials for CD. Subcutaneous administration of this agent at the higher dose of $20 \mu \mathrm{g} / \mathrm{kg}$ was associated with significant increases in PHA induced $\gamma$-interferon production compared with placebo, and an increase in TNF $\alpha$ levels that did not reach significance. ${ }^{24}$

The purpose of this study was threefold: to look for association between these four promoter polymorphisms of the TNF $\alpha$ and IL10 genes in a well characterised Australian CD patient cohort (table 1) compared with a carefully matched control population; to further investigate those SNPs that proportioned differently in the CD population in a detailed phenotype-genotype analysis; and finally, to determine whether the TNF $\alpha$ and ILl0 genes act synergistically in determining $\mathrm{CD}$ phenotype.

\section{PATIENTS AND METHODS \\ Subjects}

The 304 CD patients included in this study are a consecutive series of cases prospectively recruited into a longitudinal IBD research protocol from 1994. All patients were recorded on our IBD database together with relevant phenotypic information including disease distribution, behaviour, and duration, surgery, smoking, and histological data such as granulomas. 


\begin{tabular}{|c|c|}
\hline Clinical characteristic & $\begin{array}{l}\text { No. in CD } \\
\text { population }\end{array}$ \\
\hline Total & 304 \\
\hline Women:men & 192:112 \\
\hline Mean age now (years) & 40.9 \\
\hline Mean age at diagnosis (years) & 28.4 \\
\hline Mean disease duration (years) & 12.5 \\
\hline Familial:sporadic & $93: 211$ \\
\hline \multicolumn{2}{|l|}{ Location } \\
\hline Ileal/ileocaecal & 134 \\
\hline Colonic & 53 \\
\hline lleal and colonic & 112 \\
\hline Perianal alone & 4 \\
\hline \multicolumn{2}{|l|}{ Disease behaviour* } \\
\hline Stricturing & 75 \\
\hline Penetrating & 107 \\
\hline Inflammatory & 86 \\
\hline Ever stricturing & 123 \\
\hline Never stricturing & 145 \\
\hline Immunosuppressive therapy & 179 \\
\hline Any Crohn's-related surgery & 236 \\
\hline Bowel resection & \\
\hline Granulomas & 150 of 253 \\
\hline \multicolumn{2}{|l|}{ Smoking habit at diagnosis $\uparrow(\%)$ : } \\
\hline Never & $118(41)$ \\
\hline Current & $146(51)$ \\
\hline Ex-smoker & $23(8)$ \\
\hline \multicolumn{2}{|c|}{$\begin{array}{l}\text { *Disease behaviour available for } 268 \text { patients. } † \text { Smoking } \\
\text { data available for } 287 \text { patients. All clinical data were } \\
\text { obtained from the Royal Brisbane \& Women's Hospital } \\
\text { Irritable Bowel Disease (IBD) patient database containing } \\
\text { patients who were recruited from the Brisbane region. Ethics } \\
\text { approval and informed consent were obtained from all } \\
\text { participants. }\end{array}$} \\
\hline
\end{tabular}

Clinical records upon which these assessments were made were available for all patients in the study, from diagnosis to current. Presence of ileal disease was based upon direct ileoscopy and histology and/or small bowel contrast examination. Patients joined the programme by giving their informed and written consent for entry of their clinical history on to a dedicated IBD database, and provision of a blood sample for studying the genetics of IBD. In each case $\mathrm{CD}$ diagnosis was confirmed using established clinical, radiological, endoscopic, and histological guidelines. ${ }^{25}{ }^{26}$ Disease behaviour was based upon the Vienna classification for $C D$, designating them as having predominant stricturing, penetrating, or inflammatory disease (non-stricturing, nonpenetrating). ${ }^{26}$ Patients were also subdivided into those who had ever/never had a stricture (as defined by the Vienna classification) but independent of the presence or absence of penetrating disease. Disease distribution was classified as ileal (including ileocaecal disease), colonic, ileocolonic, or pure perianal disease. Control subjects $(n=231)$ were recruited from a longitudinal, population based twin study. One twin from each pair was taken as a control and matched with cases for age, sex, and ethnicity.

The respective human research ethics committees of the Royal Brisbane \& Women's Hospital and the Queensland Institute of Medical Research approved all recruitment protocols and genetic studies. Informed consent was obtained from all participants.

\section{Genotyping}

Genomic DNA was isolated from peripheral blood monocytes using a standard proteinase K/high salt extraction method. ${ }^{27}$ $\mathrm{CD}$ patients and controls were genotyped for four promoter polymorphisms in the $T N F \alpha(-308 \mathrm{G} / \mathrm{A},-857 \mathrm{C} / \mathrm{T})$ and $I L 10$ (-592C/A, -1082G/A) genes by PCR-RFLP as described previously. ${ }^{16} 1{ }^{19}$ Investigators performing genotyping were blinded to patients' clinical characteristics, those carrying out the phenotyping were blinded to genotypes, and the majority of the statistical analysis was carried out by individuals working outside the IBD research programme to minimise any potential bias.

\section{Statistical analysis}

Genotype and allele frequencies for CD cases and healthy controls for the four SNPs were determined. Significant differences between cases and controls were calculated using a $\chi^{2}$ test for all SNPs except TNF $\alpha-857$, where a Fisher's exact test was used because the number of observed TT genotypes was $<5$ in the control group. Maximum likelihood estimates of haplotype frequencies were calculated using haplotype and regression analysis packages (brlr, haplo.stats) in the $R$ statistical program. ${ }^{28}$ Genotype-phenotype analysis was only performed for SNPs where $p$ was $<0.2$ in case-control analysis.

Association of SNP genotypes to risk factors for CD severity was analysed using a univariate logistic regression model to examine the significance of any association between CD phenotype and a given SNP. Analyses comparing means and proportions in each category used a $\chi^{2}$ test (or Fisher's exact test if required). Stratification of CD patients for presence/ absence of any CARD15 variant (R702W, G908R, Leul007insC) was conducted and the univariate analysis repeated. Logistic regression analysis was also conducted to assess the significance of associations, after adjusting for relevant biological variables (age at diagnosis, disease duration, family type, disease site, disease behaviour, and presence/absence of granulomas) that attained a $\mathrm{p}$ value $\leqslant 0.2$ at the univariate level. Previous studies indicate that these "primary or biological" variables are potentially significant in determining disease evolution and expression, ${ }^{26}$ and therefore should be considered in a multivariate analysis. Clinical variables including use of immunosuppression and need for surgery represent consequences of disease expression.

Analysis of combined IL10-1082 and TNF $\alpha-857$ genotypes with disease phenotype was conducted by creating a new two level variable where we compared the difference between having more than two associated mutations and two or less. This was achieved by grouping patients carrying at least three associated alleles (that is, IL10-1082G/TNF $\alpha-857 \mathrm{C}$ alleles associated with higher circulating levels of each cytokine: GG/CC, GG/CT, and GA/CC) and comparing with patients carrying two or less associated alleles (that is, the remaining genotype combinations) as above. This analysis was repeated with stratification of patients for CARD15 genotype (R702W, G908R, Leu1007insC).

\section{RESULTS}

\section{Clinical characteristics of patient population}

The major clinical characteristics of this CD population are given in table 1 . In addition to the disease behaviour based upon the Vienna classification, $46 \%$ of patients $(n=123)$ were reclassified as having an intestinal stricture independent of penetrating disease, and defined as either narrowing of the intestinal lumen with proximal dilatation on contrast examination and/or clear evidence of small bowel obstruction on any radiological examination.

\section{Genotype and allele frequencies of IL 10 and TNF $\alpha$ SNPs}

Genotype analysis showed a significant difference in frequencies for the IL10-1082 polymorphism between cases and controls $(p=0.03$; table 2$)$, but not for the IL10-592 variant $(p=0.28)$. While the TNF $\alpha-308$ polymorphism showed no association with disease $(p=0.72)$, there was evidence of an 
association with TNF $\alpha-857$ according to Fisher's test $(p=0.14)$, due to the absence of the TT genotype in the control population (table 2). Allele frequencies for the two $\mathrm{TNF} \alpha$ SNPs were similar for both cases and controls, while CD patients had slightly higher frequencies of IL10-592A $(p=0.12)$ and ILl0-1082G $(p=0.12)$ alleles compared with controls (data not shown).

\section{Haplotype analysis}

Haplotype analysis of the two IL10 SNPs showed that all four haplotypes were present in the Australian population. This represents the first report of the GA haplotype in any IBD population. This haplotype was observed in very low frequency in both cases and controls (table 3), while the remaining three haplotypes (GC, AC, and $\mathrm{AA}$ ) were observed at similar frequencies to previous reports. ${ }^{15} 1621$ Comparison of case-control haplotype frequencies showed a trend towards a significant difference $\left(\chi^{2}=6.53 ; \mathrm{p}=0.09\right)$. Haplotype analysis of the two TNF $\alpha$ SNPs showed that all four haplotypes were present in the Australian population in similar frequencies as previously reported. ${ }^{16}$ There were no significant differences between cases and controls (data not shown).

\section{Genotype-phenotype associations}

To further test associations between IL10-1082, TNF $\alpha-857$, and $\mathrm{CD}$, we conducted univariate and multivariate analyses to determine whether these two SNPs contribute to a specific CD phenotype. Variables were included in the multivariate analysis if $\mathrm{p}$ was $\leqslant 0.2$ at the univariate level. Gene-gene interaction with CARD15 variants was also investigated.

\section{IL 10-1082}

Univariate analysis for IL10-1082 and clinical variables was conducted comparing all three genotypes (table 4). Patients with the GG genotype were more likely to have complex disease behaviour (stricturing and/or penetrating, 77\%) compared with those carrying the AA genotype (57\%, OR $2.60,95 \%$ CI 1.15 to $5.87, p=0.06)$. Similarly, the GG genotype was associated with more stricturing disease at any stage (52\%) compared with the AA genotype (33\%, OR 2.13, $95 \%$ CI 0.99 to $4.59, \mathrm{p}=0.04$ ). Patients with a GG genotype were also more likely to have undergone any CD surgery (83\%), compared with the AA genotype (69\%, OR 2.20, 95\% CI 0.92 to $5.30, p=0.16$ ) but there was no association between genotype and bowel resection. These associations

\begin{tabular}{|c|c|c|c|}
\hline \multicolumn{4}{|c|}{$\begin{array}{l}\text { Table } 3 \text { Estimated haplotype frequencies of } \\
\text { the combined IL10-592C/A and IL10-1082G/ } \\
\text { A promoter polymorphisms at position }\end{array}$} \\
\hline \multicolumn{2}{|l|}{ IL10 } & \multicolumn{2}{|c|}{ Frequency } \\
\hline-592 & -1082 & $\begin{array}{l}C D \\
(n=232)\end{array}$ & $\begin{array}{l}\text { Controls } \\
(n=182)\end{array}$ \\
\hline$C$ & G & 0.490 & 0.439 \\
\hline c & A & 0.292 & 0.374 \\
\hline A & G & 0.036 & 0.031 \\
\hline A & A & 0.182 & 0.156 \\
\hline
\end{tabular}

were stronger in patients with no CARD15 mutation (disease behaviour: OR $3.85,95 \%$ CI 1.48 to $9.98, \mathrm{p}=0.02$; stricturing: OR $4.05,95 \%$ CI 1.47 to $11.19, \mathrm{p}=0.01$; any CD surgery: OR $3.03,95 \%$ CI 1.11 to $8.26, p=0.04$ ), but these factors were not associated with the presence of any CARD15 variant. Multivariate analysis correcting for familial CD, duration of disease and disease site showed that patients carrying the $G$ allele had higher odds of their disease exhibiting either stricturing $\left(\mathrm{OR}_{\mathrm{GA}} 2.05,95 \% \mathrm{CI} 0.85\right.$ to 4.96 ; $\mathrm{OR}_{\mathrm{GG}} 2.10,95 \%$ CI 0.73 to 6.05$)$ or penetrating $\left(\mathrm{OR}_{\mathrm{GA}} 1.47,95 \%\right.$ CI 0.65 to 3.31; $\mathrm{OR}_{\mathrm{GG}} 2.90,95 \%$ CI 1.15 to 7.37 ) behaviour, although this did not reach significance $(p=0.10)$. Similar analysis of the ever/never stricturing disease variable maintained the association with IL10-1082G $(p=0.02)$, where patients carrying the $G$ allele had higher odds of ever having stricturing disease $\left(\mathrm{OR}_{\mathrm{GA}} 2.90,95 \% \mathrm{CI} 1.36\right.$ to 6.19 ; $\mathrm{OR}_{\mathrm{GG}}$ $2.57,95 \%$ CI 1.10 to 6.03 ). Multivariate analysis of any CD surgery correcting for familial CD, duration of disease, disease site and phenotype showed that patients carrying IL10-1082G had slightly higher odds of ever having surgery for their disease $\left(\mathrm{OR}_{\mathrm{GA}} 1.64,95 \%\right.$ CI 0.57 to 4.74 ; $\mathrm{OR}_{\mathrm{GG}} 1.59$, $95 \%$ CI 0.44 to 5.81 ), although this was not significant $(\mathrm{p}=0.64)$.

\section{TNF $\alpha 857$}

Owing to the small proportion of TNF $\alpha$-857TT genotypes observed in our cohort $(n=5)$ both univariate and multivariate analyses of TNF $\alpha-857$ genotype-phenotype associations was carried out using combined data (combined proportions of $\mathrm{CT}+\mathrm{TT}$ compared with CC). Univariate analysis

\begin{tabular}{|c|c|c|c|c|c|c|}
\hline $\begin{array}{l}\text { Genotype } \\
\text { frequencies }\end{array}$ & $C D$ & Controls & OR & $95 \% \mathrm{Cl}$ & $\chi^{2}$ & $p$ value \\
\hline IL10-592 & $n=236$ & $n=231$ & & & & \\
\hline CC & 0.60 & 0.67 & Ref & & 2.52 & 0.28 \\
\hline CA & 0.36 & 0.30 & 1.33 & 0.90 to 1.97 & & \\
\hline AA & 0.04 & 0.03 & 1.56 & 0.56 to 4.31 & & \\
\hline IL10-1082 & $n=234$ & $n=188$ & & & & \\
\hline GG & 0.27 & 0.27 & Ref & & 6.91 & $0.03+$ \\
\hline $\mathrm{GA}$ & 0.51 & 0.40 & 1.25 & 0.78 to 1.99 & & \\
\hline AA & 0.22 & 0.33 & 0.67 & 0.42 to 1.07 & & \\
\hline TNF $\alpha-308$ & $\mathrm{n}=304$ & $n=217$ & & & & \\
\hline GG & 0.65 & 0.69 & Ref & & 0.67 & 0.72 \\
\hline GA & 0.30 & 0.28 & 1.14 & 0.82 to 1.58 & & \\
\hline AA & 0.05 & 0.03 & 1.85 & 0.80 to 4.26 & & \\
\hline TNF $\alpha-857$ & $\mathrm{n}=275$ & $n=217$ & & & & \\
\hline CC & 0.84 & 0.86 & Ref & & 3.99 & $0.14^{*} \dagger$ \\
\hline $\mathrm{CT}$ & 0.14 & 0.14 & 0.98 & 0.59 to 1.56 & & \\
\hline$\pi$ & 0.02 & 0.00 & - & - & & \\
\hline
\end{tabular}

*Fisher's exact test. †Genotype-phenotype analysis was only performed for SNPs where $p<0.2$ in case-control analysis. 
Table 4 Association of IL10-1082 SNP genotypes (GG $v$ GA $v$ AA) with risk factors for $C D$ severity calculated using a univariate logistic regression model

\begin{tabular}{|c|c|c|c|c|c|}
\hline \multirow[b]{2}{*}{ Phenotype } & \multicolumn{3}{|c|}{ IL10-1082 genotype } & \multirow{2}{*}{$\begin{array}{l}\text { Test } \\
\text { statistic }\end{array}$} & \multirow{2}{*}{$\begin{array}{l}\mathbf{p} \\
\text { value }\end{array}$} \\
\hline & GG $(n=64)$ & GA $(n=119)$ & AA $(n=51)$ & & \\
\hline Group distribution (years) & & & & $\mathrm{F}$ & \\
\hline Mean (SD) age at diagnosis & $29.4(1.7)$ & $27.6(1.3)$ & $28.9(1.5)$ & 0.46 & 0.63 \\
\hline Mean (SD) disease duration & $12.7(0.9)$ & $12.7(0.7)$ & $11.0(0.9)$ & 1.28 & 0.28 \\
\hline Genotype distribution (n (\%)) & & & & & \\
\hline Any $C D$ surgery & & & & $\chi^{2}$ & \\
\hline No & $11(17.2)$ & $24(20.2)$ & $16(31.4)$ & & \\
\hline Yes & $53(82.8)$ & $95(79.8)$ & $35(68.6)$ & 3.73 & 0.16 \\
\hline \multicolumn{6}{|l|}{ Phenotype } \\
\hline Stricturing & $17(27.4)$ & 40 (34.2) & $13(25.5)$ & & \\
\hline Penetrating & $31(50.0)$ & $40(34.2)$ & $16(31.4)$ & & \\
\hline Non-stricturing & $14(22.6)$ & $37(31.6)$ & $22(43.1)$ & 8.26 & 0.08 \\
\hline \multicolumn{6}{|l|}{ Stricturing } \\
\hline Never & $30(48.4)$ & $54(46.2)$ & $34(66.7)$ & & \\
\hline Ever & $32(51.6)$ & $63(53.8)$ & $17(33.3)$ & 6.27 & 0.04 \\
\hline
\end{tabular}

Group distributions for age at diagnosis and duration of disease are shown for the three genotypes. Only risk factors with a $p$ value $<0.2$ are shown. These were further tested in multivariate analysis.

(table 5) highlighted significant associations between TNF $\alpha$ 857CC and stricturing/penetrating disease behaviour (69\%), compared with the CT/TT genotypes (50\%, OR $2.24,95 \%$ CI 1.15 to $4.37, \mathrm{p}=0.03)$, and with familial $\mathrm{CD}(\mathrm{CC}=28 \% v \mathrm{CT} /$ $\mathrm{TT}=14 \%$, OR $2.4,95 \%$ CI 0.97 to $5.96, \mathrm{p}=0.05$ ).

These associations were again found in patients with no CARD15 mutation (disease behaviour, OR 2.94, 95\% CI 1.23 to 7.14, $\mathrm{p}=0.02$; familial CD, OR 4.52, 95\% CI 1.02 to 20.00, $\mathrm{p}=0.05$ ), but these factors were not associated with any CARD15 variant. There was evidence suggesting possible associations with disease site $(\mathrm{p}=0.08)$, disease duration $(p=0.06)$, and bowel resection $(p=0.13)$. When stratified

Table 5 Univariate analysis of TNF $\alpha-857$ SNP genotypes comparing the proportions of the $-\mathrm{T}$ group (CC) to the $+\mathrm{T}$ group $(\mathrm{CT}+\mathrm{TT})$ with risk factors for $\mathrm{CD}$ severity

\begin{tabular}{|c|c|c|c|c|}
\hline \multirow[b]{2}{*}{ Phenotype } & \multicolumn{2}{|c|}{ TNF $\alpha-857$ genotype } & \multirow[b]{2}{*}{$\begin{array}{l}\text { Test } \\
\text { statistic }\end{array}$} & \multirow[b]{2}{*}{$\begin{array}{l}p \\
\text { value }\end{array}$} \\
\hline & $\begin{array}{l}C C \\
(n=232)\end{array}$ & $\begin{array}{l}C T+T \\
(n=43)\end{array}$ & & \\
\hline Group distribution (years) & & & $t$ & \\
\hline $\begin{array}{l}\text { Mean (SD) age at diagnosis } \\
\text { (years) }\end{array}$ & $28.7(0.9)$ & $26.1(1.9)$ & 1.45 & 0.23 \\
\hline $\begin{array}{l}\text { Mean (SD) disease duration } \\
\text { (years) }\end{array}$ & $11.6(0.5)$ & $13.8(1.0)$ & 3.54 & 0.06 \\
\hline \multicolumn{5}{|l|}{ Genotype distribution (n (\%)) } \\
\hline No & $167(72.0)$ & $37(86.1)$ & & \\
\hline \multicolumn{5}{|l|}{ Bowel resection } \\
\hline No & 75 (32.3) & 19 (44.2) & & \\
\hline Yes & $157(67.7)$ & $24(55.8)$ & 2.27 & 0.13 \\
\hline \multicolumn{5}{|c|}{ 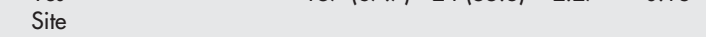 } \\
\hline lleal & $99(43.4)$ & $12(27.9)$ & & \\
\hline Ileocolonic & $82(36.0)$ & $23(53.5)$ & & \\
\hline Colonic & $47(20.6)$ & $8(18.6)$ & 5.07 & 0.08 \\
\hline \multicolumn{5}{|l|}{ Phenotype } \\
\hline Stricturing & $70(30.8)$ & $9(21.4)$ & & \\
\hline Penetrating & $87(38.3)$ & $12(28.6)$ & & \\
\hline Non-stricturing & $70(30.9)$ & $21(50.0)$ & 5.83 & 0.05 \\
\hline \multicolumn{5}{|l|}{ Granuloma } \\
\hline No & $101(46.1)$ & $14(34.2)$ & & \\
\hline Yes & $118(53.9)$ & $27(65.8)$ & 2.01 & 0.16 \\
\hline \multicolumn{5}{|l|}{ Stricturing } \\
\hline Never & $117(51.5)$ & $28(66.7)$ & & \\
\hline Ever & $110(48.5)$ & $14(33.3)$ & 3.26 & 0.07 \\
\hline $\begin{array}{l}\text { Group distribution for age a } \\
\text { for the two groups. Only risk } \\
\text { These were further tested in }\end{array}$ & $\begin{array}{l}\text { diagnosis a } \\
\text { factors with } \\
\text { nultivariate }\end{array}$ & $\begin{array}{l}\text { id duration } \\
\text { a p value of } \\
\text { nalysis. }\end{array}$ & $\begin{array}{l}f \text { disease } \\
<0.2 \text { are }\end{array}$ & $\begin{array}{l}\text { shown } \\
\text { shown. }\end{array}$ \\
\hline
\end{tabular}

for CARD15 variants, disease site became moderately significant in the group with no CARD15 variants $(\mathrm{p}=0.04)$. Multivariate analysis of familial CD correcting for duration of disease, phenotype, and disease site maintained the association with TNF $\alpha-857 C \mathrm{C}(\mathrm{p}=0.03$; OR $3.12 ; 95 \%$ CI 1.15 to 8.46). Multivariate analysis of disease phenotype indicated weak evidence of the CC genotype carrying higher odds of either stricturing (OR 2.51; 95\% CI 1.00 to 6.27 ) or penetrating (OR 2.27; 95\% CI 1.01 to 5.12 ) behaviour $(p=0.06)$, whereas disease site showed no significant association at this level.

\section{Combined IL 10/TNF $\alpha$ genotypes and disease phenotype}

To examine whether IL10-1082 and TNF $\alpha-857$ genotypes might work synergistically to influence CD behaviour, we created a new two level variable to compare the difference between having more than two associated mutations and having two or fewer. Patients carrying at least three associated alleles (that is, IL10-1082/TNF $\alpha-857$ alleles associated with higher circulating levels of each cytokine; GG/CC, GG/CT, and GA/CC) were compared with patients carrying two or fewer associated alleles (the remaining genotype combinations). This analysis showed an even stronger positive association between IL10-1082G and TNF $\alpha-857 \mathrm{C}$ with stricturing behaviour, which persisted after multivariate analysis ( $\mathrm{p}=0.007$; OR $2.37 ; 95 \%$ CI 1.26 to 4.43 ). There was also a moderate positive association with familial CD ( $\mathrm{p}=0.04 ;$ OR $2.14 ; 95 \%$ CI 1.04 to 4.42 ). These findings were unchanged after stratification for CARD15. A test for the presence of effect modification was also conducted; however, this was not significant.

\section{DISCUSSION}

IL10 and TNF $\alpha$ are regarded as key players in development and control of the inflammatory response, and hence are thought to play an important role in chronic inflammatory and autoimmune disorders, including IBD. In this study, we investigated the role of four potentially functional IL10 and TNF $\alpha$ SNPs in a large, well characterised CD cohort that had previously been genotyped for the major CARD15 SNPs (R702W, G908R, Leu1007insC).

There was significant evidence that IL10-1082 genotype distributions differed between cases and controls, and there was weak evidence of an association with TNF $\alpha-857$, whereas IL10-592 and TNF $\alpha-308$ showed no such association. Haplotype analysis of the two IL10 SNPs did not strengthen 
the observed genotype association with IL10-1082. Multiple previous studies have investigated TNF $\alpha$ SNPs in CD, with both positive and negative results. ${ }^{16}{ }^{18-20} 22$ Many of these have included small cohorts (35-124 patients) or have been highly selected, including those with fistulising disease alone, or patients treated with infliximab for refractory disease. ${ }^{18} 2022$ Two larger studies using association and linkage approaches have shown positive association with the TNF $\alpha 857$ SNP and positive linkage with the TNF-HLA region on chromosome $6 .{ }^{16}{ }^{29}$ SNPs within the IL10 gene have received less attention despite it being an attractive candidate, as it has a known role in generation of regulatory $\mathrm{T}$ cells and the phenotype of the IL10 knockout model. ${ }^{8}$ Studies thus far have been limited to a negative linkage study, ${ }^{30}$ which used $89 \mathrm{CD}$ affected sibling pairs but limited the ILIO analysis to one microsatellite within the $5^{\prime}$ promoter region of the gene, and both positive $(\mathrm{n}=38)$ and negative $(\mathrm{n}=142)$ association studies. ${ }^{15} 21$ Importantly, there has been limited phenotype-genotype analysis carried out for both TNF $\alpha$ and IL10 genes. The only study to address this found positive associations between $\mathrm{TNF} \alpha$ and steroid dependence and penetrating disease behaviour $(\mathrm{n}=193)$. $^{31}$

Based on our case-control analysis and results of previous studies, phenotype-genotype correlations were explored for IL10-1082 and TNF $\alpha-857$ SNPs, both individually and together. Multivariate analyses demonstrated significant associations between these two SNPs and CD phenotype. Specifically, the IL10-1082G allele and those cases with the GG genotype carried a significantly greater risk of developing stricturing disease at any stage. Risk of requiring surgery was slightly increased with this SNP but did not reach significance after correction, suggesting that the underlying phenotypic association is with disease behaviour. TNF $\alpha$ 857CC showed a moderate association with familial CD and with either stricturing or penetrating disease behaviour, while there was a similar association with developing stricturing disease independent of penetrating CD.

The association between ILl0 and an aggressive CD phenotype is initially surprising, given its proposed role in murine models of IBD. ${ }^{9}$ However, both recent and previous data have suggested an immunostimulatory role for IL10. Specifically, IL10 stimulates proliferation of activated B cells, mast cells, and activated $\mathrm{CD}^{+}{ }^{+} \mathrm{T}$ cells. ${ }^{23}$ In human studies, parenteral IL10 has been disappointing as a therapeutic agent for both $\mathrm{CD}$ and for graft versus host disease. ${ }^{1132}$ Doses $>8 \mu \mathrm{g} / \mathrm{kg}$ are clinically less effective and may be associated with increased side effects, while even higher doses of $20 \mu \mathrm{g} /$ $\mathrm{kg}$ show ex vivo increased $\gamma$-interferon production. ${ }^{24}$ In CD patients, there does not appear to be an IL10 deficiency in the ileum or in peripheral blood. ${ }^{33}$ In the diseased ileum, IL10 does not downregulate proinflammatory cytokines and in fact may lead to increased TNF $\alpha$ production. ${ }^{33}$ The explanation for these observations is not as yet clear but may involve interleukin-12 acting synergistically with IL10 in the inflamed tissue sites, but not in normal specimens. Alternatively, CD patients may possess an abnormality within the IL10 pathway further downstream (the IL10 receptor). ${ }^{34}$ Given that the discovery of the CARD15 susceptibility gene has led to CD being described as a form of immunodeficiency, exogenous IL10 or increased local production may influence the antimicrobial defences of the intestinal epithelium adversely and allow increased access to commensal bacteria. ${ }^{35}$ However, this was not supported by our own analysis in that stratification for CARD15 mutations did not influence associations between IL10 and disease phenotype.

The association between TNF $\alpha-857$ and aggressive disease behaviour is in keeping with its properties as a proinflammatory cytokine, with the therapeutic benefits of antiTNF therapy for refractory $C D$, and with the only other phenotype-genotype TNF study (although this solely investigated the -308 polymorphism). ${ }^{10}{ }^{31}$ Given that anti-TNF therapy is not advocated for CD patients with fixed intestinal stenoses, the present results suggest that early therapy with these agents may delay the development of stricturing and penetrating disease, particularly in those carrying the $\mathrm{G}$ allele or GG genotype. Pharmacogenetic studies that have investigated the relationship between TNF/TNF-R polymorphisms and response to remicade have thus far been negative. ${ }^{202}$ However, these studies have been based around large, multicentre clinical trials with reasonably broad inclusion criteria, in patients with well established and longstanding disease, and were investigating associations between genotype and early response to therapy. Such correlations may be better determined by introducing an anti-TNF agent at a much earlier stage of the disease to control inflammation, promote healing, and thus prevent strictures and fistulae. The positive association between the $\mathrm{TNF} \alpha-857 \mathrm{G}$ allele and stricturing/penetrating disease in our study supports this approach.

The other major finding for the TNF $\alpha 857$ polymorphism is the significant association between the CC genotype and familial CD; $43 \%$ of patients carrying the CC genotype had a positive family history of IBD compared with only $14 \%$ of those carrying other genotypes (CT/TT). This result fits well with data from previous studies, which used multiplex IBD families exclusively, or a combination of multiplex families and sporadic cases to show association between TNF $\alpha-857 \mathrm{C}$ and CD. ${ }^{16} 19$

Combining the IL10-1082GG and TNF $\alpha$-857CC genotypes demonstrated a significant synergistic effect, where patients carrying at least three of four alleles associated with increased cytokine production ( $\mathrm{G}$ and $\mathrm{C}$ ) showed a stronger association with stricturing disease compared with either polymorphism alone $(\mathrm{p}=0.007$; OR $2.37 ; 95 \%$ CI 1.26 to 4.43 ), which was unaffected by CARD15 status. This is the first report of these two cytokines potentially working together to create a specific disease phenotype, and needs to be confirmed in an independent cohort of patients that have been phenotyped in the same manner using the Vienna classification. It is not clear what mechanism may be at play here. However, a common mediator of chronic inflammation may be a $\mathrm{CD}^{+} \mathrm{T}$ cell. This cell population is essential for the development of ileitis in the TNF $\triangle$ ARE model of CD, in which animals overexpress TNF $\alpha$ protein up to threefold. ${ }^{7}$ Similarly, IL10 can stimulate and increase cytolytic activity in $\mathrm{CD}^{+} \mathrm{T}$ cells, and rescue peripheral blood $\mathrm{T}$ cell clones from apoptotic cell death. ${ }^{23}$ These and other potential mediators of the chronic inflammatory process need to be explored in further observational and functional studies.

Our investigation of IL10 and TNF SNPs in an Australian CD population suggests that specific SNPs in the promoter regions of both the TNF $\alpha$ and IL10 genes may be useful to predict $C D$ behaviour with respect to disease severity or surgical risk. This may be clinically useful in shaping treatment of the disease at an earlier stage. The above results will need to be verified in an independent ethnically similar cohort using the same methods of assessment of disease related variables as in this study. Future investigation of genes in the IL10 downstream pathway may provide further insight into the genetic contribution to $\mathrm{CD}$ pathogenesis.

\section{ACKNOWLEDGEMENTS}

This project was funded by the Royal Brisbane \& Women's Hospital Foundation and Australian Crohn's \& Colitis Association (Qld). IBD database supported by Pfizer Australia. E V Fowler is the recipient of a Reginald Ferguson Fellowship, R Eri received Queensland Cancer Fund \& Royal Brisbane \& Women's Hospital Foundation grants, and G Hume a National Health \& Medical Research Council PhD Scholarship. 


\section{Authors' affiliations}

E V Fowler, R Eri*, G Hume, S Johnstonet, G L Radford-Smith, Inflammatory Bowel Diseases Laboratory, Clinical Research Centre, Royal Brisbane \& Women's Hospital Research Foundation, Queensland Institute of Medical Research, Brisbane, Australia

E V Fowler, School of Medicine, University of Queensland, Brisbane, Australia

G Hume, D Templeton, G L Radford-Smith, Department of

Gastroenterology, Royal Brisbane \& Women's Hospital, Brisbane, Australia

N Pandeya, D Lincoln, Cancer \& Population Studies, Queensland Institute of Medical Research, Brisbane, Australia

*Present address: Department of Oral Pathology, School of Medicine, Indiana University, Indianapolis, USA

†Present address: Forensic Biology, Queensland Health Scientific Services, Archerfield, Brisbane, Australia

Competing interests: none declared

Correspondence to: Dr E V Fowler, Inflammatory Bowel Diseases Laboratory, Clinical Research Centre, Royal Brisbane \& Women's Hospital Research Foundation, Queensland Institute of Medical Research, Brisbane, Australia; bethf@qimr.edu.au

Received 21 September 2004

Revised version received 15 December 2004

Accepted 12 January 2005

\section{REFERENCES}

1 Hume G, Radford-Smith GL. The pathogenesis of Crohn's disease in the $21 \mathrm{st}$ century. Pathology 2002;34:561-7.

2 Hugot JP, Chamaillard M, Zouali H, Lesage S, Cezard JP, Belaiche J, Almer S, Tysk C, O'Morain CA, Gassull M, Binder V, Finkel Y, Cortot A, Modigliani R, Laurent-Puig P, Gower-Rousseau C, Macry J, Colombel JF, Sahbatou M, Thomas G. Association of NOD2 leucine-rich repeat variants with susceptibility to Crohn's disease. Nature 2001;411:599-603.

3 Stoll M, Corneliussen B, Costello CM, Waetzig GH, Mellgard B, Koch WA, Rosenstiel P, Albrecht M, Croucher PJ, Seegert D, Nikolaus S, Hampe J, Lengaver T, Pierrou S, Foelsch UR, Mathew CG, Lagerstrom-Fermer M, Schreiber S. Genetic variation in DLG5 is associated with inflammatory bowel disease. Nat Genet 2004;36:476-80.

4 Peltekova VD, Wintle RF, Rubin LA, Amos Cl, Huang Q, Gu X, Newman B, Van Oene M, Cescon D, Greenberg G, Griffiths AM, St George-Hyslop PH, Siminovitch KA. Functional variants of OCTN cation transporter genes are associated with Crohn disease. Nat Genet 2004;36:471-5.

5 Braegger CP, Nicholls S, Murch SH, Stephens S, MacDonald TT. Tumour necrosis factor alpha in stool as a marker of intestinal inflammation. Lancet 1992;339:89-91.

6 Stevens C, Walz G, Singaram C, Lipman ML, Zanker B, Muggia A, Antonioli D, Peppercorn MA, Strom TB. Tumour necrosis factor $\alpha$, interleukin$1 \beta$ and interleukin-6 expression in inflammatory bowel disease. Dig Dis Sci 1992;37:818-26.

7 Pizzaro T, Arseneau KO, Bamias G, Cominelli F. Mouse models for the study of Crohn's disease. Trends Mol Med 2003;9:218-22.

8 Kuhn R, Lohler J, Rennick D, Rajewsky K, Muller W. Interleukin-10-deficient mice develop chronic enterocolitis. Cell 1993;75:263-74.

9 Asseman C, Mauze S, Leach MW, Coffman RL, Powrie F. An essential role for interleukin 10 in the function of regulatory $T$ cells that inhibit intestinal inflammation. J Exp Med 1999;190:995-1003.

10 Targan SR, Hanauer SB, van Deventer SJ, Mayer L, Present DH, Braakman T, DeWoody KL, Schaible TF, Rutgeerts PJ. A short-term study of chimeric monoclonal antibody cA2 to tumour necrosis factor afor Crohn's disease. Crohn's disease cA2 Study Group. N Engl J Med 1997;337:1029-35.

11 Schreiber S, Fedorak RN, Nielsen OH, Wild G, Williams CN, Nikolaus S, Jacyna M, Lashner BA, Gangl A, Rutgeerts P, Isaacs K, van Deventer SJ, Koningsberger JC, Cohard M, LeBeaut A, Hanauer SB. Safety and efficacy of recombinant human interleukin-10 in chronic active Crohn's disease. Gastroenterology 2000;119:1461-72.

12 Berg D, Davidson N, Kuhn R, Muller W, Menon S, Holland G, ThompsonSnipes L, Leach MW, Rennick D. Enterocolitis and colon cancer in interleukin10 -deficient mice are associated with aberrant cytokine production and CD4 Th1-like responses. J Clin Invest 1996;98:1010-20.
13 Turner DM, Williams DM, Sankaran D, Lazarus M, Sinnott PJ, Hutchinson IV. An investigation of polymorphism in the interleukin-10 gene promoter. Eur J Immunogenet 1997;24:1-8.

14 Wilson AG, Symons JA, McDowell TL, McDevitt HO, Duff GW. Effects of a polymorphism in the human tumor necrosis factor $\alpha$ promoter on transcriptional activation. Proc Natl Acad Sci US A 1997;94:3195-9.

15 Tagore A, Gonsalkorale WM, Pravica V, Hajeer AH, McMahon R, Whorwell PJ, Sinnott PJ, Hutchinson IV. Interleukin-10 (IL10) genotypes in inflammatory bowel disease. Tissue Antigens 1999;54:386-90.

16 van Heel DA, Udalova IA, De Silva AP, McGovern DP, Kinouchi Y, Hull J, Lench NJ, Cardon LR, Carey AH, Jewell DP, Kwiatkowski D. Inflammatory bowel disease is associated with a TNF polymorphism that effects an

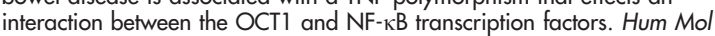
Genet 2002;11:1281-9.

17 Edwards-Smith CJ, Jonsson J, Purdie DM, Bansal A, Shorthouse C, Powell EE. Hepatology 1999;30:526-30.

18 Gonzalez S, Rodrigo L, Martinez-Borra J, Lopez-Vazquez A, Fuentes D, Nino P, Cadahia V, Saro C, Dieguez A, Lopez-Larrea C. TNF- $\alpha-308$ A promoter polymorphism is associated with enhanced TNF- $\alpha \alpha$ production and inflammatory activity in Crohn's patients with fistulizing disease. Am J Gastroenterol 2003;98:1 101-6.

19 O'Callaghan NJ, Adams KE, van Heel DA, Cavanaugh JA. Association of TNF-alpha-857C with inflammatory bowel disease in the Australian population. Scand J Gastroenterol 2003:38:533-4.

20 Mascheretti S, Hampe J, Kuhbacher T, Herfarth H, Krawczak M, Folsch UR, Schreiber S. Pharmacogenetic investigation of the TNF/TNF-receptor system in patients with chronic active Crohn's disease treated with infliximab. Pharmacogen J 2002;2:127-36.

21 Klein W, Tromm A, Griga T, Fricke H, Folwaczny C, Hocke M, Eitner K, Marx M, Runte M, Epplen J. The IL10 gene is not involved in the predisposition to inflammatory bowel disease. Electrophoresis 2000;21:3578-82.

22 Louis E, Vermeire S, Rutgeerts $M$, De Vos M, Van Gossum A, Pescatore P, Fiasse R, Pelckmans P, Reynaert H, D' Haens G, Malaise M, Belaiche J. A positive response to infliximab in Crohn disease: Association with a higher systemic inflammation before treatment but not with -308 TNF gene polymorphism. Scand J Gastroenterol 2003;37:818-24.

23 Groux H, Cottrez F. The complex role of interleukin-10 in autoimmunity. $J$ Autoimmun 2003;20:281-5.

24 Tilg $\mathrm{H}$, van Montfrans C, van den Ende A, Kaser A, van Deventer SJH, Schreiber S, Gregor M, Ludwiczek O, Rutgeerts P, Gasche C, Koningsberger JC, Abreu L, Kuhn I, Cohard M, LeBeaut A, Grint P, Weiss G Treatment of Crohn's disease with recombinant human interleukin 10 induces the proinflammatory cytokine interferon $\gamma$. Gut 2002;50:191-5.

25 Lennard-Jones JE. Classification of inflammatory bowel disease. Scand J Gastroenterol Suppl 1989;170:2-6.

26 Gasche C, Scholmerich J, Brynskov J, D'Haens G, Hanauer SB, Irvine EJ, Jewell DP, Rachmilewitz D, Sachar DB, Sandborn WJ, Sutherland LR. A simple classification of Crohn's disease: report of the working party for the World Congresses of Gastroenterology, Vienna 1998. Inflamm Bowel Dis 2000;6:8-15.

27 SA Miller, DD Dykes, and HF Polesky. A simple salting out procedure for extracting DNA from human nucleated cells. Nucleic Acids Res 1988;16:1215

28 R Development Core Team. R: A language and environment for statistical computing. Vienna, Austria: R Foundation for Statistical Computing, 2004 www.R-project.org.

29 Yang H, Plevy SE, Taylor K, Tyan D, Fischel-Ghodsian N, McElree C, Targan SR, Rotter Jl. Linkage of Crohn's disease to the major histocompatibility complex region is detected by multiple non-parametric analyses. Gut 1999;44:519-26.

30 Parkes M. Satsangi J, Jewell D. Contribution of the IL-2 and IL10 genes to inflammatory bowel disease (IBD) susceptibility. Clin Exp Immunol 1998;113:28-32

31 Louis E, Peeters M, Franchimont D, Seidel L, Fontaine F, Demolin G, Croes F, Dupont $P$, Davin L, Omri S, Rutgeerts P, Belaiche J. Tumour necrosis factor (TNF) gene polymorphism in Crohn's disease (CD): Influence on disease behaviour? Clin Exp Immunol 2000;1 19:64-8.

32 Blazar BR, Taylor PA, Smith S, Vallera DA. Interleukin-10 administration decreases survival in murine recipients of major histocompatibility complex disparate donor bone marrow grafts. Blood 1995;85:842-51.

33 Colpaert S, Vanstraelen K, Liu Zhanju, Penninckx F, Geboes K, Rutgeerts P, Ceuppens J. Decreased lamina propria effector cell responsiveness to interleukin-10 in ileal Crohn's disease. Clinica Immunol 2002;102:68-76.

34 Gasche C, Grundtner P, Zwirn P, Reinisch W, Shaw SH, Zdanov A, Sarma U, Williams LM, Foxwell BM, Gangl A. Novel variants of the IL10 receptor 1 affect inhibition of monocyte TNF-alpha production. J Immunol 2003; 170:5578-82.

35 Folwaczny C, Glas J, Torok HP. Crohn's disease: an immunodeficiency? Eur J Gastroenterol Hepatol 2003;15:621-6. 